\title{
ARTYKUtY
}

Klio. Czasopismo poświęcone dziejom Polski i powszechnym

PL ISSN 1643-8191, t. 52 (1)/2020, s. 89-109

(c) (1) $\Theta$

\section{Znaczenie polityczno-militarne Würzburga i innych państw Rzeszy Niemieckiej w początkach wojny o sukcesję hiszpańską w oczach dyplomacji francuskiej"*}

\section{The political and military significance of Würzburg and other countries of the German Reich at the beginning of the war for Spanish succession in the eyes of French diplomacy}

Streszczenie: Pod koniec XVII w. Europa Zachodnia stała u progu wojny o sukcesję hiszpańską. W związku z bezpotomną śmiercią Karola II Habsburga zarówno Ludwik XIV, jak

Instytut Historii, Uniwersytet Opolski, ul. Strzelców Bytomskich 2, 45-084 Opole, sawicki4@wp.pl,nr ORCID: 0000-0001-5318-7145.

** Artykuł jest wynikiem badań naukowych związanych z realizacją grantu Narodowego Centrum Nauki w Krakowie nr DEC 2017/01/X/HS3/00482 na realizację pojedynczego działania naukowego pt. „Elity społeczno-polityczne Wielkiego Księstwa Litewskiego w świetle raportów dyplomatów francuskich i angielskich w II połowie XVII w." oraz badań naukowych możliwych dzięki uzyskaniu stypendium, którego fundatorem był biskup Würzburga w ramach środków przyznawanych w Polskiej Misji Historycznej przy Uniwersytecie Juliusza Maksymiliana w Würzburgu - tytuł projektu: „Kontakty dyplomatyczne biskupów Würzburga z dworem francuskim w II połowie XVII w. w świetle zachowanej, francuskojęzycznej korespondencji”, realizacja - listopad 2016 r. 
i Leopold VI byli zainteresowani obsadzeniem tronu w Madrycie. Mimo wcześniejszych porozumień i uzgodnień dotyczących ewentualnego podziału Hiszpanii Francja i cesarz szykowali się do wojny. Najpewniej - ponieważ analizowany dokument nie ma daty w 1700 r. dyplomaci francuscy podjęli się próby eksplikacji możliwości ewentualnego poparcia politycznego i militarnego Ludwika XIV przez niektórych książąt i biskupów niemieckich. Na tej podstawie opracowano niezwykle interesujący memoriał, który jest podstawą rozważań w tym artykule.

Abstract: At the end of the $17^{\text {th }}$ century, Western Europe was on the verge of a war for Spanish succession. In connection with the childless death of Karol II Habsburg, both Louis XIV and Leopold VI were interested in filling the throne in Madrid. Despite previous agreements and arrangements regarding the possible division of Spain, France and the emperor were preparing for war. Probably, because the analyzed document does not have a date, in 1700 French diplomats attempted to analyze the possibility of political and military support of Louis XIV by some German princes and bishops. In connection with this, they prepared a very interesting document, which is the basis for the author's considerations of this article.

Słowa kluczowe: Francja, Niemcy, Ludwik XIV, Schönborn, Würzburg

Keywords: France, Germany, Louis XIV, Schönborn, Würzburg

Furopa początku XVIII w. zmagała się z dwoma niezwykle istotnymi Ckonfliktami militarnymi, które wpłynęły na jej kształt na kolejne dziesięciolecia. Zachodnia części kontynentu była uwikłana w wojnę o sukcesję hiszpańską, której jeden z elementów stanowi istotę tego artykułu. Na wschodzie od 1700 r. trwała natomiast wielka wojna północna, która zdecydowała o układzie sił w Europie Środkowo-Wschodniej na kolejne dziesięciolecia. Dyplomacja francuska już na początku wojny o sukcesję hiszpańską interesowała się niektórymi państwami Rzeszy, a także Danią, analizując ich możliwości wojskowe wobec rodzącego się konfliktu. Niestety dotyczący tego, przechowywany w Staadarchiv Würzburg (Residenz) rękopis o numerze 2420, nie ma daty, ale wiele informacji w nim zawartych świadczy, że powstał on najprawdopodobniej w 1700 r. lub na 
przełomie XVII i XVIII stulecia ${ }^{1}$. Wymieniony dokument został także wydrukowany w drugiej dekadzie XVIII w. w zbiorze Des Heiligen Romischen Reichs-Staats Acta, von jetzigen 18. seculo sich anfahend, in welchen incht allein die bey annoch währenden Reichs-Tag eingereichte Staats-Schrifften, [...] Besten zum [...] Cassandro Thücelio, Bd. 1, ale nie został on zaopatrzony w odpowiedni aparat naukowy i przeanalizowany pod kątem zawartych $\mathrm{w}$ nim informacji ${ }^{2}$.

Omówienie wymienionego wyżej dokumentu wymaga analizy w odpowiednich częściach artykułu nieco odleglejszych chronologicznie okresów w dziejach politycznych Rzeszy Niemieckiej, a zabieg ten wydaje się konieczny, biorąc pod uwagę informacje umieszczone w badanym rękopisie. Pierwszym tego typu działaniem jest ogólna chociaż charakterystyka sytuacji politycznej na tle wojny o sukcesję hiszpańską, która rzuca nieco światła na późniejsze, francuskie analizy możliwego w zachodnich państwach niemieckich poparcia własnych działań politycznych i militarnych, przy czym w tym przypadku chodzi w większości o obszary znajdujące się na linii Renu. Brak takiego syntetycznego omówienia sytuacji politycznej na krótko przed 1700 r. spowodowałby pewien niedosyt związany z analizą materiału źródłowego, który nieosadzony w odpowiednich realiach historycznych stwarzałby wrażenie jedynie cząstkowego omówienia wyrażonej w tytule problematyki.

Kolejnym wspominanym wyżej zabiegiem ściśle łączącym się z eksplikacją wykazanej w tytule tematyki jest konieczność sięgnięcia do faktografii początku lat 70. XVII w., w szczególności do wojny holenderskiej i znaczenia, jakie miał w niej Würzburg i biskup Johann Philipp von Schönborn, zresztą niezwykle wytrawny polityk i dyplomata, odgrywający bardzo istotną rolę w rozgrywkach politycznych w Rzeszy Niemieckiej tamtego okresu. Wydarzenia te tylko z pozoru wydają się nieco oderwane od czasu powstania omawianego memoriału, ponieważ przy analizie możliwości militarnych

\footnotetext{
1 État présent des Princes, qui on fait la Requisition, s.l., s.a., Staadarchiv Würzburg (Residenz), Schönborn - Archiv, Korespondenz - archiv Johann Philipp, nr 2420, s.p.

2 Des Heiligen Romischen Reichs-Staats Acta, von jetzigen 18. seculo sich anfahend, in welchen incht allein die bey annoch währenden Reichs-Tag eingereichte Staats-Schrifften, [...] Besten zum [...] Cassandro Thücelio, Bd. 1, Frankfurt-Leipzig 1715, s. 617-618. Tekst zawarty w wersji drukowanej nie odbiega od oryginału i jest jego kopią.
} 
Würzburga autor anonimowego francuskiego dokumentu z przełomu XVII i XVIII w. często powoływał się właśnie na wydarzenia z lat 1672-1673. Wydaje się, że ukształtowały one w pewien sposób polityczne postrzeganie Francji przez kolejnych, następujących po Schönbornie, biskupów, co znalazło wyraz w badanym memoriale. Wyjaśnienie, choćby w ogólny sposób, zawiłych problemów politycznych początku lat 70. XVII w. wydaje się zatem $\mathrm{w}$ takim kontekście nieuniknione i celowe. Pomoże to bowiem zrozumieć, choć oczywiście w uproszczony nieco sposób, funkcję, jaką pełnił Würzburg w polityce Francji wymienionego wyżej okresu.

Już od 1696 r., a więc jeszcze rok przed pokojem w Rijswijk kończącym wojnę Francji z koalicją augsburską, wiedziano, że schorowany Karol II ostatecznie umrze, nie pozostawiając po sobie potomka mogącego przejąć iberyjską spuściznę tamtejszych Habsburgów. Wymieniony władca już od najmłodszych lat niezwykle często chorował; dopiero w wieku 7 lat nauczył się chodzić, a 10 - czytać. Długo podtrzymywano mu samoczynnie opadającą rękę, aby mógł podpisywać najważniejsze dokumenty państwowe. Ważnym elementem wpływającym na jego zdrowie, nie tylko fizyczne, było zbyt bliskie pokrewieństwo rodziców - ojciec Filip IV poślubił córkę swojej siostry Marię Annę Austriacką. Ostatecznie Karol II nie mógł mieć dzieci, co otwierało najróżniejsze spekulacje dotyczące następców tronu³

Kandydatów ze względu na powiązania dynastyczne było wielu. Wnukami króla hiszpańskiego Filipa III byli zarówno Ludwik XIV, jak i cesarz Leopold VI. Kolejnymi pretendentami do tronu byli: syn elektora bawarskiego, kilkuletnie dziecko, Józef Ferdynand, książę sabaudzki Wiktor Amadeusz II i król Portugalii - Piotr II. Połączenie tronu hiszpańskiego z tronem wiedeńskim czy burbońskim byłoby politycznie niezwykle skomplikowane wobec delikatnej równowagi sił w Europie, która zostałaby nieodwracalnie naruszona. W tej sytuacji wobec braku zgody na wnuka Ludwika XIV, Filipa, księcia d'Anjou, lub któregoś z synów cesarza Leopolda VI zdecydowano się na arbitralne rozwiązanie proponowane przez Wilhelma III Orańskiego. Cesarzem miał zostać najsłabszy z kandydatów - Józef Ferdynand,

3 C. Taracha, Egzorcyzmy, muzyka i alkowa. Kilka Uwag na temat problemów zdrowotnych wtadców Hiszpanii w XVII-XVIII w., „Teka Komisji Historycznej O.L. PAN” 2014, t. 11, s. 49-50. 
posiadłości hiszpańskie miały ulec podziałowi, a cały układ zagwarantowano odpowiednim traktatem podpisanym w Hadze w 1698 r. W tej sytuacji Karol II spisał testament, w którym władzę i wszystkie swoje posiadłości powierzył księciu bawarskiemu. Niestety ten zmarł na ospę 5 lutego $1699 \mathrm{r}$. i po raz kolejny musiano szukać następcy ostatniego Habsburga na tronie hiszpańskim. Ludwik XIV ponownie zaczął wysuwać jako pretendenta do korony swojego wnuka, a cesarz Leopold VI niechętny podziałowi imperium zamierzał obsadzić w Madrycie swojego syna - arcyksięcia Karola. Król francuski, chcąc uniknąć wojny, nadal pertraktował z Wilhelmem III Orańskim i ostatecznie podpisano w marcu 1700 r. nowy traktat rozbiorowy Hiszpanii. Umierając, Karol II planował przekazać całość państwa Habsburgowi wiedeńskiemu, na co nie chciał się oczywiście zgodzić Wersal. Jednocześnie stany hiszpańskie, widząc możliwość utrzymania całego państwa w gwarancjach Francji Ludwika XIV, zaproponowały mu, aby tron objął wspomniany wyżej Filip, książę d'Anjou. Oczywiście każde z rozwiązań oznaczało wojnę, na którą osłabiona po konflikcie dziewięcioletnim Francja nie była przygotowana. Mimo to starzejący się Ludwik XIV, chcąc spełnić największe marzenie swojego życia, ogłosił swojego wnuka Filipa królem Hiszpanii - Filipem $V^{4}$.

Od pierwszych dni konfliktu, mimo ważnych sojuszy zawartych przez Francję, politycy i dyplomaci wersalscy poszukiwali innych kierunków ewentualnego aliansu przeciw Habsburgom, a wydaje się, że zwyczajowym polem takiej eksploracji była Rzesza Niemiecka. Wnuka Ludwika XIV poparł prawie natychmiast elektor bawarski i namiestnik Niderlandów Maksymilian Emanuel Wittelsbach, który niedługo potem dał niezwykły wyraz swojego zaangażowania w nowy sojusz polityczny. Jego żona Teresa Kunegunda Sobieska urodziła mu 12 lipca 1701 r. piątego syna, którego ojcem chrzestnym został Filip V. Wkrótce sojusz z Francją podpisała Sabaudia,

4 E. Rostworowski, Historia powszechna wiek XVIII, Warszawa 1994, s. 203-204; V. Cronin, Ludwik XIV, tłum. K. Molek, Warszawa 2001, s. 283-285; W. St. Magdziarz, Ludwik XIV, Wrocław-Warszawa-Kraków 2004, s. 241, 249, 253-255.

5 M. Komaszyński, Teresa Kunegunda Sobieska, Warszawa 1982, s. 83-84. 
stając się satelitą Wersalu, ale dobrze opłacaną kwotą w zupełności wystarczającą na utrzymanie 8000 piechoty i 2500 jazdy $^{6}$.

W analizowanym manuskrypcie noszącym tytuł „État présent des Princes, qui on fait la Réquisition”, w którym anonimowy autor omawia możliwości rekrutacyjne niektórych księstw Rzeszy Niemieckiej, które przynajmniej teoretycznie sprzyjały Francji, już na samym początku wymienia Würzburg. Zaznacza on, że w czasie wojny nie było tam więcej jak 6000 ludzi, którzy zapewne mogliby spełniać warunki rekrutacji wojskowej. Oceniający możliwości mobilizacyjne wymienionego terytorium uznał jednak, że w obecnej chwili nie można brać pod uwagę większej liczby żołnierzy niż $4000^{7}$.

Przedstawiciele Leopolda VI również nie zamierzali kwestii związanych z możliwościami mobilizacyjnymi na terenie państw niemieckich pozostawić przypadkowi. Już w 1697 r., a więc nieco wcześniej niż we Francji, zrobiono spis oddziałów, które były na utrzymaniu cesarskim, w tym także z Frankonii. Wymieniono tu również Würzburg, który wystawił dwa bataliony, czyli maksymalnie od 1600 do 2000 żołnierzy, pod dowództwem niewymienionego z imienia pułkownika Wallenfelsa. W tym samym roku ze wspomnianych dwóch batalionów z Würzburga wyodrębniono jeden regiment, który został oddelegowany do ochrony niestety nieokreślonego miejsca, którym prawdopodobnie była linia Renu ${ }^{8}$. Od Węgra na służbie cesarskiej - Jánosa Erdőda Pálffyego - miało pochodzić pięć kompanii husarii. Kolejny oddział to regiment dragonii pochodzący z miasta Wangenheim, a następny to regiment kirasjerów z Wartensleben. Do tego wszystkiego dochodziły jeszcze wojska palatynów: jeden regiment kawalerii

6 W. St. Magdziarz, op. cit., s. 256; J. A. Lynn, Wojny Ludwika XIV 1667-1714, Oświęcim 2015, s. 254.

7 État présent des Princes, qui on fait la Requisition, s.l., s.a., Staadarchiv Würzburg (Residenz), Schönborn - Archiv, Korespondenz - archiv Johann Philipp, nr 2420, s.p.; Des Heiligen Romischen Reichs-Staats Acta..., s. 617.

${ }^{8}$ Nn do Conseiller Pensonaire 24 mars/3 avril 1697, The Britsh Library (dalej: BL), Add MS 28899, k. 136; Lettres historiques. Contenant ce qui se passe de plus important en Europe; et les réflexions nécessaire sur ce sujet, t. 11, mois de janvier 1697, Haga 1697. 
z Hochkirken, „un de Dragons de Jungheim” i jeden z księstwa Saxe-Mainungen?

Francuz w angielskiej służbie dyplomatycznej, Philipp Plantamour, 23 czerwca 1697 r. donosił w swoim raporcie z Frankfurtu londyńskiemu sekretarzowi stanu Williamowi Ellisowi o armii znajdującej się nad górnym Renem. Wspomniał on także, że dzień wcześniej przybył drogą wodną regiment piechoty z Würzburga pod dowództwem niewymienionego z imienia pułkownika Fuchsa. Otrzymał on rozkaz stawienia się w obozie Gustavenburg, gdzie miał oczekiwać na regimenty Palatynatu w składzie: jednego dragonii hrabiego de Vehlen, a drugiego - kirasjerów niewymienionego z imienia Pfenningera. Planowano, że po zakończeniu koncentracji jednostki otrzymają rozkaz przekroczenia Renu i podjęcia tam odpowiednich działań, o których niestety Plantamour nie wspominał ${ }^{10}$.

Jak widać, już pod koniec XVII w. Würzburg, a przede wszystkim jego oddziały wojskowe miały swoje znaczenie na scenie politycznej w przededniu wojny o sukcesję hiszpańską. Na ważną rolę tego miasta wskazuje także kolejny dokument zatytułowany „Les Deputez de l'Empire pour le traités de paix avec la France”, w którym w części poświęconej kolegium książąt wymienione jest właśnie interesujące mnie miasto obok Bremy, Magdeburga, Anhalt i innych ${ }^{11}$.

Wracając jednak do analizowanego wyżej dokumentu francuskiego, należy zaznaczyć, że omawiając w nim kwestie Würzburga, jego autor nawiązał do znacznie wcześniejszego niż zasadnicze rozważania wydarzenia, a mianowicie elekcji Johanna Philippa II von Greiffenclaua. Jego wybór, zdaniem Francuzów, nastąpił $\mathrm{w}$ wyniku wielu intryg różnych dworów, w tym palatyńskiego, oraz powiązań rodziców kandydata z dworem wiedeńskim. Odniesiono się również do podobnej zdaniem autora dokumentu sytuacji w Würzburgu w 1673 r., kiedy to musiano wkroczyć do biskupstwa. Z kontekstu zdania wynikało zaś, że sytuacja obecnie mogła się

9 Nn do Conseiller Pensonaire 24 mars/3 avril 1697, BL, Add MS 28899, k. 136.

10 Ph. Plantamour do William Ellis, Frankfurt 13/23 juin 1697, BL, Add MS 28899, k. 270-271.

11 Les Deputez de l'Empire pour le Traités de Paix avec la France, s.l, s.a., ale prawdopodobnie czerwiec lub lipiec 1697, BL, Add MS 28899, k. 362. 
powtórzyć. Wspomniano także o wybitnym wodzu z lat 70. XVII w. na służbie habsburskiej - generale Raimondo, hrabim Montecúccolim, który w latach $1672-1673$ z powodzeniem prowadził działania zaczepne na terenie Rzeszy Niemieckiej we Frankonii i nad Renem przeciw wojskom francuskim marszałka Henriego de la Tour d'Auvergne, wicehrabiego Turenne $^{12}$. Ostatni z wymienionych miał natomiast za zadanie nie dopuścić do wkroczenia wojsk cesarskich do Niderlandów holenderskich, przy czym dowodzeni przez niego żołnierze mieli za wszelką cenę unikać grabieży ludności cywilnej, co wobec dużych problemów z zaopatrzeniem było raczej nie do uniknięcia. Zresztą na pewno pamiętano sposób i ilość pobieranych przez niego kontrybucji w 1647 i 1648 r. wespół ze Szwedami, którzy rujnowali tamtejsze tereny, co musiało mieć wpływ na stosunek do wojsk Ludwika XIV także w początkach lat 70. XVII stulecia. Mimo że wojska francuskie były wówczas uważane za sojusznicze, to zapewne w pamięci mieszkańców biskupstwa Würzburga na długo pozostał oddział 300 żołnierzy, bezlitośnie grabiących przez trzy dni okolice, o których mówiono wprost: „300 bestii” ${ }^{13}$.

Kolejnym zadaniem marszałka Francji było założenie bazy we Frankonii i wywieranie w ten sposób nacisku na niezdecydowaną Bawarię, choć pozostającą w orbicie wpływów Ludwika XIV. Ostatecznie nie wywiązał się on z tego zadania, Montecúccoli wraz z Wilhelmem III obległ Bonn, którego francuska załoga skapitulowała 12 listopada 1673 r. Turenne wycofał się zaś na leża zimowe do Alzacji i innych części Niemiec ${ }^{14}$.

Analizowany rękopis nawiązuje do nakreślonej powyżej sytuacji. Jego autor wspominał, że ówczesny biskup Würzburga, Johann Hartmann von Rosenbach, wysłał rzekomo do francuskiego dowódcy niewymienionego z imienia pułkownika Cronberga list, prawdopodobnie w celu podjęcia

12 État présent des Princes, qui on fait la Requisition, s.l., s.a., Staadarchiv Würzburg (Residenz), Schönborn - Archiv, Korespondenz - archiv Johann Philipp, nr 2420, s.p.; Des Heiligen Romischen Reichs-Staats Acta..., s. 617.

${ }^{13} \mathrm{Nn}$ do nn, s.l, s.a., ale raczej 1647 lub 1648 r., Staadarchiv Würzburg (Residenz), Schönborn - Archiv, Korespondenz - archiv Johann Philipp, nr 2417, s.p.; Politica varia, Staadarchiv Würzburg (Residenz), Schönborn - Archiv, Korespondenz - archiv Johann Philipp, nr 2419, s.p.; J. A. Lynn, op. cit., s. 120.

${ }_{14}$ J. A. Lynn, op. cit., s. 120. 
wspólnych działań lub rozpoczęcia ewentualnych rozmów, być może związanych z rozmieszczeniem na terenie biskupstwa wojsk francuskich. Plany te zostały przerwane przez zbliżające się oddziały cesarskie pod wodzą Montecúccolego, co ostatecznie zmusiło biskupa Rosenbacha do wydania zgody na stacjonowanie na swoim terenie jednostek habsburskich ${ }^{15}$. Być może próbował on, raczej nieskutecznie, prowadzić politykę neutralności wobec walczących stron na wzór nieżyjącego już wtedy Johanna Phillipa von Schönborna.

W związku z powyżej wykazaną faktografią wydaje się w tym miejscu uzasadnione omówienie w formie schematycznej sytuacji politycznej biskupstwa Würzburga w latach 70. XVII w., która była istotna dla funkcjonowania wymienionego terytorium. Analiza ta rzuci nieco więcej światła na wydarzenia, do których nawiązywał Francuz, i nieco rozjaśni zawarte w dokumencie zawiłości polityki Ludwika XIV na południu Rzeszy Niemieckiej.

Biskup Würzburga Johann Phillip von Schönborn, który przez ostatnie lata swojego życia znajdował się w zasadzie w orbicie wpływów wiedeńskich, zmarł 12 lutego 1673 r. W 1672 r. starał się on jednak zachować neutralności wobec konfliktu Ludwika XIV z cesarzem, mając zapewne nadzieje na uchronienie swoich posiadłości przed przemieszczającymi się po terenie Rzeszy wrogimi jednostkami i utrzymanie jak najdłużej pokoju na jej terenie. W trakcie konfliktu zbrojnego Schönborn planował pełnić funkcję pośrednika w rozmowach pokojowych, ale wobec okupacji południowych terenów biskupstwa ostatecznie opowiedział się po stronie cesarza, w czym pomogły także rozmowy prowadzone na temat ewentualnego aliansu w Wiedniu ${ }^{16}$. Mimo to nadal był uważany przez polityków paryskich za osobę wartą poświęcenia jej większej uwagi, niż wynikałoby to z jego sojuszu z cesarzem. Można domniemywać, że Schönborn nadal

15 État présent des Princes, qui on fait la Requisition, s.l., s.a., Staadarchiv Würzburg (Residenz), Schönborn - Archiv, Korespondenz - archiv Johann Philipp, nr 2420, s.p.; Des Heiligen Romischen Reichs-Staats Acta..., s. 617.

16 G. Mentz, Johann Philipp von Schönborn, Kurfürst von Mainz, Bischof von Würzburg und Worms, 1605-1673: ein Beitrag zur Geschichte des 17. Jahrhunderts, Jena 1896-1899, s. 175; Johann Philipp I. von Schönborn 1642-1673, w: Germania sacra, Bd. 7, Berlin 2011, s. 338-339. 
odgrywał istotną rolę w planach politycznych Francji. Dodatkowo, zapewne ze względów propagandowych, informowano go na bieżąco o kolejnych zwycięstwach Ludwika XIV ${ }^{17}$. Ten z kolei w swojej korespondencji do Johanna Philippa zarówno w 1672 r., jak i 9 stycznia 1673 r. nie ukrywał sympatii, jaką darzył adresata, zapewne nieco kurtuazyjnej, ale na pewno pokazującej jego rolę wśród książąt Rzeszy, a w szczególności zachodnich terenów cesarstwa. W pierwszym z wymienionych listów z 25 lipca 1672 r. Ludwik XIV wyraził zadowolenie z wzajemnych dobrych kontaktów i sympatii, jaką darzy go Schönborn, co zdaniem monarchy francuskiego było widoczne zwłaszcza w czasie ostatniej kampanii wojennej ${ }^{18}$. W kolejnym liście, tym razem z 24 września 1672 r., król ponowie zapewniał Johanna Philippa o swojej przyjaźni i przekazał wyrazy uznania z powodu jej dotrzymywania przez biskupa. Nadmienił również o swoich planach pokojowych i raczej nieuniknionych kontrybucjach na terenie Rzeszy Niemieckiej, ale wydaje się, że miało to raczej sprawić wrażenie w pewnym stopniu usprawiedliwienia tego typu działań ${ }^{19}$. W liście z 9 stycznia 1673 r. król Francji informował Schönborna o sukcesach militarnych księcia Louisa II de Bourbon-Condé, a przy okazji ponownie zapewnił o swojej przyjaźni, którą miał nadzieję, że biskup odwzajemnia ${ }^{20}$.

Oczywiście tego rodzaju częste zwroty świadczące o przyjaźni można poczytywać za zwyczajową w takich przypadkach kurtuazję, podobnie jak tytułowanie przez Ludwika XIV Johanna Philippa „mon cousin”, które było naturalnym grzecznościowym zwrotem wykorzystywanym w dyplomacji paryskiej, choć należy przy tym zaznaczyć, że używano go w stosunku do

17 Ludwik XIV do J. Ph. von Schönborn, list bardzo zniszczony, ale raczej na pewno Paryż 8 stycznia 1673, Staadarchiv Würzburg (Residenz), Schönborn - Archiv, Korespondenz - archiv Johann Philipp, nr 2474 a s.p.

18 Ludwik XIV do J. Ph. von Schönborn, au Camp de Voxtil (?) 25 lipca 1672, Staadarchiv Würzburg (Residenz), Schönborn - Archiv, Korespondenz - archiv Johann Philipp, nr 2473 a, k. 283.

19 Ludwik XIV do J. Ph. von Schönborn, Wersal 24 września 1672, Staadarchiv Würzburg (Residenz), Schönborn - Archiv, Korespondenz - archiv Johann Philipp, nr $2473^{\mathrm{a}}$, k. 284.

${ }^{20}$ Ludwik XIV do J. Ph. von Schönborn, list bardzo zniszczony, ale raczej na pewno Paryż 8 stycznia 1673, Staadarchiv Würzburg (Residenz), Schönborn - Archiv, Korespondenz - archiv Johann Philipp, nr 2474ª s.p. 
sojuszników lub osób, których wagę w polityce francuskiej chciano w specjalny sposób zaznaczyć. Niemniej takie zwroty ukazują, jaką rolę w dyplomacji francuskiej odgrywał Johann Philipp von Schönborn.

O zaangażowaniu biskupa Würzburga $\mathrm{w}$ kwestie związane $\mathrm{z}$ pokojowym uregulowaniem konfliktu zbrojnego świadczą przekazy źródłowe, w których wymieniany jest on jako mediator w wojnie holenderskiej w 1672 r. Prawdopodobnie 7 sierpnia, ponieważ miesiąc jest nieczytelny, 1672 r. Ludwik XIV, wyrażając przy okazji swoją przyjaźń, informował Schönborna o ewentualnych, planowanych rozmowach pokojowych. Nie ukrywał on także zadowolenia z zaangażowania Johanna Philippa w działania mające na celu przywrócenie pokoju między walczącymi stronami. Król Francji kończył korespondencję słowami mówiącymi o przyjaźni i zaufaniu między nadawcą a adresatem listu - „votre amitié et de votre confiance” 21 .

Burbon w liście do Schönborna z 24 września tego samego roku nawiązał do jego działań na rzecz pokoju w Rzeszy - „L'affection que vous avez toujours pour le maintien de la paix et de la tranquillité de l'Allemagne m'étant parfaitement connu"22. W związku z tym Ludwik XIV wysłał do niego swojego zaufanego przedstawiciela, markiza de Vaubruy, który był wyposażony zapewne w jakieś, raczej szerokie pełnomocnictwa. Dzięki nim mógł poufnie rozmawiać z Johannem Philippem o bieżącej sytuacji polityczno-wojskowej. Miał on także przekazać istotne, choć oczywiście w korespondencji nie wymieniono jakie, informacje $\mathrm{e}^{23}$.

Pierwszy dokument, który należy w tym miejscu omówić, a który niezbicie świadczy o roli Schönborna w planach dyplomacji francuskiej, pochodzi z 19 grudnia 1672 r. Realizowana przez wymienionego polityka neutralności i chęci mediacji w negocjacjach pokojowych znalazły uznanie Ludwika XIV, który wyraził z tego powodu zadowolenie, przekazane $\mathrm{w}$ analizowanym $\mathrm{w}$ tym miejscu dokumencie. Wymieniony władca

21 Ludwik XIV do J. Ph. von Schönborn, Wersal 7 września (?) 1672, Staadarchiv Würzburg (Residenz), Schönborn - Archiv, Korespondenz - archiv Johann Philipp, nr 2473ª k. 282.

22 Ludwik XIV do J. Ph. von Schönborn, Wersal 24 września 1672, Staadarchiv Würzburg (Residenz), Schönborn - Archiv, Korespondenz - archiv Johann Philipp, nr $2473^{\mathrm{a}}$, k. 285.

23 Ibidem. 
podkreślił znaczenie działań Johanna Philippa zmierzających do uspokojenia wojny i sytuacji polityczno-militarnej w Rzeszy, w przeciwieństwie do innych książąt i elektorów. Burbon podkreślił, że uznaje to za wyraz przyjaźni Schönborna. W dalszej części Ludwik XIV zaznaczył, że nadal jest wielce przychylny idei pokoju, a wypowiedzenie wojny Holandii było absolutnie konieczne. Memoriał opisuje również działania polityczne i militarne usprawiedliwiające podjęcie interwencji przez króla francuskiego, podkreślając wrogość ze strony Holandii oraz zajęcie przez nich obszarów nadreńskich. Mimo to Ludwik XIV nadal rzekomo pragnął sprawiedliwego pokoju i pouczał przy okazji Schönborna, że nie może żądać od niego więcej, niż on sam uzna za stosowne i co według Burbona będzie istotne dla zakończenia wojny i pacyfikacji Rzeszy Niemieckiej. Podkreślono również, że zarówno Holandia, jak i cesarstwo kierują się różnymi interesami politycznymi i żeby biskup Würzburga nie łączył ich w trakcie prowadzonych mediacji. Władca Francji stwierdził dodatkowo, że Schönborn powinien wraz z innymi książętami i elektorami Rzeszy zawrzeć pokój na podległym sobie terytorium, aby następnie móc negocjować i podpisywać podobne dokumenty z Holandią. Po raz kolejny w analizowanym memoriale poruszony został problem mediacji Johanna Philippa w kontekście ogólnych negocjacji pod kuratelą Ludwika XIV. Oczywiście nadal kwestia ta była rozgraniczana i dyplomacja francuska dyskusję o ewentualnym pośrednictwie pokojowym rozdzielała na działania względem Holandii oraz reszty państw niemieckich biorących udział w konflikcie. Zresztą nawet w Niemczech Ludwik XIV zwracał uwagę na problemy mediacyjne związane ze zmianą stanowiska niektórych książąt od początku wojny holenderskiej²4.

Oczywiście analizowany powyżej, niezwykle interesujący pod kątem działań dyplomatów francuskich, dokument w dużej mierze omawia kwestię ewentualnej mediacji Schönborna, wskazując tym samym na jego ważną rolę na ówczesnej scenie politycznej oraz w planach Ludwika XIV. Po raz kolejny można zatem uznać, że mimo, wydawałoby się, rzeczywistego funkcjonowania biskupa Würzburga w sferze wpływów cesarskich od

24 Memoriał Ludwika XIV, Wersal 19 grudnia 1672, Staadarchiv Wurzburg (Residenz), Schönborn - Archiv, Korespondenz - archiv Johann Philipp, nr 2473a s.p. 
połowy lat 70. XVII stulecia, tak naprawdę nie zaniedbywał on kontaktów z Paryżem, nadając im, jak w tym przypadku, niezwykle wyrazisty kształt.

Drugim dokumentem jest inny memoriał dotyczący mediacji i planów dyplomatycznych Schönborna związanych z toczącym się konfliktem, a którego dokładna analiza nie mieści się w zakresie tematycznym prezentowanego szkicu. Niemniej należy zaznaczyć, że dokument ten obejmuje kompleksowy opis sytuacji politycznej i wzajemnych relacji walczących stron oraz możliwości rozwiązania problemów przy pomocy mediatorów, z których wymieniano mi.in. króla szwedzkiego Karola XI, który został zaakceptowany przez zainteresowanych książąt Rzeszy Niemieckiej ${ }^{25}$.

Wracając jednak do analizy dokumentu z przełomu XVII i XVIII w. należy zauważyć, że kolejną osobą, o której wspomniał jego autor w części analizującej sytuację polityczną i militarną Würzburga, był biskup Münster Friedrich Christian Plettenberg. Francuz uznał, że pozyskał on do swojej polityki Karla III Josepha von Lothringena, barona Tastungen, którego tytułował „Ministre de Würzburg”, a w rzeczywistości był on już wówczas biskupem Ołomuńca i Osnabrücka ${ }^{26}$.

Dyplomata Ludwika XIV konkludował swoje spostrzeżenia stwierdzeniem, że nie można na razie liczyć na wojska „cet évêque”, choć czy chodzi o biskupa Münsteru, czy Würzburga, tego niestety nie precyzował. Wynikało to z konieczności pozostawienia oddziałów na terenie biskupstwa, zapewne jednak würzburskiego, raczej dla ochrony niż działań ofensywnych, dopóki sytuacja polityczna z cesarzem nie będzie do końca jasna - „si n'est pas bien avec l'Empereur" ${ }^{27}$.

Kolejnym miastem, którego sytuację polityczną poddano analizie w omawianym dokumencie, było wymienione powyżej Münster. Polityk

25 Le Memoire qui lui a esté nouvellement présenté par le Baron de Schönborn au nomde son Eminance Monsieur l'Electeur Maÿence a conmandé d'y rendre la response qui suit, 11 (?) lutego 1673, Staadarchiv Würzburg (Residenz), Schönborn - Archiv, Korespondenz - archiv Johann Philipp, nr 2394, s.p.

26 Ibidem; https://www.deutsche-biographie.de/sfz17409.html\#adbcontent (dostęp: 17.06.2018).

27 État présent des Princes, qui on fait la Requisition, s.l., s.a., Staadarchiv Würzburg (Residenz), Schönborn - Archiv, Korespondenz - archiv Johann Philipp, nr 2420, s.p.; Des Heiligen Romischen Reichs-Staats Acta..., s. 617. 
francuski nie pomylił się, twierdząc, że tamtejszy biskup, wspomniany wyżej Friedrich Christian von Plettenberg, był zdecydowanie nieprzychylny Francji. Autor dokumentu nawiązał jednak od razu do wcześniejszych czasów, pontyfikatu Christopha Bernharda von Galena, skłóconego kilkukrotnie z miastem, pobierającego obce subsydia, które miały być przeznaczone na wspieranie działań wojennych w sojuszu z Ludwikiem XIV przeciw Niderlandom ${ }^{28}$. Von Galen do 1674 r. był rzeczywiście francuskim sprzymierzeńcem i w zamian za poparcie otrzymywał wysokie dotacje z Paryża przeznaczone na prowadzenie aktywnej polityki wojennej. Już jednak w 1675 r. jego działania cechowały się przede wszystkim pragmatyzmem, a sam biskup skupił się w większości na zabiegach dyplomatycznych, pozostawiając nieco na uboczu sprawy wojenne. Zresztą działalność wojskowa przyniosła biskupstwu sporo długów, których von Galen do końca życia nie był w stanie spłacić ${ }^{29}$. W tym samym roku przeszedł na stronę cesarza i walczył razem z nim przeciw Francji w sojuszu z Brandenburgią i Danią ${ }^{30}$.

Podobnie postąpił w późniejszym czasie biskup Münster Friedrich Christian von Plettenberg, który 12 maja 1689 r. przystąpił do sojuszu polityczno-wojskowego z Anglią, Stanami Generalnymi i cesarzem Leopoldem VI skierowanego przeciw Francji. Widocznym efektem przymierza były subsydia otrzymywane od państw morskich - Anglii i Holandii, w kwocie 20000 talarów miesięcznie na zaciąg żołnierzy ${ }^{31}$.

Autor anonimowego dokumentu z przełomu XVII i XVIII w., zwracając oczywiście uwagę na nieprzychylne stanowisko wobec Francji zarówno Münster, jak i tamtejszego biskupa, zaznaczył, że może on wystawić co

28 État présent des Princes, qui on fait la Requisition, s.l., s.a., Staadarchiv Würzburg (Residenz), Schönborn - Archiv, Korespondenz - archiv Johann Philipp, nr 2420, s.p.; Des Heiligen Romischen Reichs-Staats Acta..., s. 617; P. Corstiens, Bernard van Galen, vorst-bisschop van Münster. Historische schets van een belangrijk tijdperk der XVII e eeuw en van de Nederlandsche Republiek, vooral omstreeks 1672, Die Gids, Zeven en dertigste Jaargang, Berde serie, 1873, s. 166.

29 https://www.deutsche-biographie.de/gnd118520709.html\#ndbcontent (dostęp: 27.06.2018).

30 The Diary of Samuel Pepys, w: https://www.pepysdiary.com/encyclopedia/9100/ \#Biography (dostęp: 27.06.2018).

31 F. Scharlach, Fürstbischof Friedrich Christian V. Plettenberg und die münsterische Politik im Koalitionskriege 1688-97, „Westfälische Zeitschrift” 1937, Bd. 93, s. 108. 
najwyżej oddział liczący 6000 ludzi, którzy byli mu jednak niezbędni do ochrony własnych granic. Poza swoje terytorium, zdaniem Francuza, mógł on wysłać najwyżej 3000 do 4000 żołnierzy - „3 ou 4000 hommes hors de son pays" 32 . W analizowanym dokumencie dyplomatycznym można również znaleźć informacje dotyczące pobieranych przez biskupa Münster dotacji finansowych zarówno z Londynu, jak i Niderlandów Północnych, choć jaka była ich wysokość, niestety autor nic nie wspomina, ale można domniemywać, że chodzi tu o sumę wymienioną powyżej, czyli 20000 talarów ${ }^{33}$.

Kolejne informacje polityczne związane z biskupstwem Münster dotyczą tamtejszej, wydawałoby się rychłej, elekcji na najwyższe stanowisko duchowne. W memoriale uznano, że cesarz zagrażał i był przeciwny elekcji „le grand Doyen de Paderborn”, który był jednocześnie bratem tamtejszego biskupa. W tym przypadku chodziło o Wilhelma Hermanna Ignaza Ferdinanda Reichsfreiherra von Wolff-Metternicha zu Grachta, który był bratem księcia-biskupa Paderborn Hermanna Wernera von Wolff-Metternicha zur Grachta ${ }^{34}$. Francuz uznał również, że biskup Münster był już słabego zdrowia, a sytuacja ta zagrażała tamtejszym interesom Ludwika XIV. Stwierdzono bowiem, że jeśli urząd ten przejdzie w ręce „le grande Maitre

32 État présent des Princes, qui on fait la Requisition, s.l., s.a., Staadarchiv Würzburg (Residenz), Schönborn - Archiv, Korespondenz - archiv Johann Philipp, nr 2420, s.p.; Des Heiligen Romischen Reichs-Staats Acta..., s. 617.

33 État présent des Princes, qui on fait la Requisition, s.l., s.a., Staadarchiv Würzburg (Residenz), Schönborn - Archiv, Korespondenz - archiv Johann Philipp, nr 2420, s.p.; Des Heiligen Romischen Reichs-Staats Acta..., s. 617.

34 L. Moreri, Le grand dictionnaire historique, ou Le melange curieux de l'histoire sacrée et profane [...], t. 13, Paris 1748, s. 13-14; P. R. Richard et autres religieux Dominicains des Couvents du Fauxbourg, Dictionnaire universel, dogmatique, canonique, historique, géographique et chronologique des sciences ecclésiastiques [...], t. 14, 1756, s. 226. Francuzi interesowali się przebiegiem elekcji w Münster, o czym świadczą relacje przesyłane do Francji (M. de Lamberti, Mémoires pour servir à l'histoire du XVIIIe siècle, contenant les négociations, traitez, résolutions et autres documents authentiques concernant les affaires d'état: avec le supplément aux années [...], t. 14 [suplement], Amsterdam 1740, s. 305-320). 
Teutoniqué" lub biskupa Osnabrücka, to Francja straci jakiekolwiek wpływy polityczne w tym regionie ${ }^{35}$.

Zdaniem autora analizowanego dokumentu Kassel, które według niego było bardzo ważnym członkiem Ligii, mogło wystawić 20 kompanii piechoty po 90 ludzi i 22 pododdziały kawalerii i dragonii po 50 żołnierzy każdy. Oczywiście do tego należy także doliczyć oficerów. Dodatkowo na tamtym terenie dysponowano również garnizonami w następujących miastach i zamkach: Kassel, Ziegen (chyba chodzi tutaj o Ziegenberg), Hain, Marbourg i Rindelen (Rinteln). Tamtejszy władca Karl I von Hessen-Kassel utrzymywał także dobre kontakty z Londynem za pośrednictwem barona Tettau ${ }^{36}$. Niestety nie do końca wiadomo, o którego z przedstawicieli tej rodziny chodziło, na początku XVIII w. kilku z nich pełniło bowiem różnorakie funkcje wojskowe i polityczne. Najbardziej prawdopodobnym jest tutaj Julius Ernst von Tettau, który był znany na wyspach brytyjskich już od lat 80. XVII w. Najprawdopodobniej zatem przez niego Karl I von Hessen-Kassel zapewniał o swoim rozważnym postępowaniu w trakcie rodzącego się konfliktu europejskiego ${ }^{37}$.

Kolejnym miastem, które Francuzi poddali analizie militarnej w interesującym mnie dokumencie, było Darmstadt. Według autora memoriału nie było ono w stanie wystawić więcej niż 1200-osobowy oddział. Dodatkowo żołnierze ci mieli za zadanie ochraniać miasto Gießen. Tamtejsze władze współpracowały z cesarzem i Kassel, w związku z czym w dokumencie oceniono, że nie ma możliwości zerwania jego więzów z Leopoldem VI „il ne se séparera pas de l'Empereur n y de Cassel”38.

35 État présent des Princes, qui on fait la Requisition, s.l., s.a., Staadarchiv Würzburg (Residenz), Schönborn - Archiv, Korespondenz - archiv Johann Philipp, nr 2420, s.p.; Des Heiligen Romischen Reichs-Staats Acta..., s. 617.

36 État présent des Princes, qui on fait la Requisition, s.l., s.a., Staadarchiv Würzburg (Residenz), Schönborn - Archiv, Korespondenz - archiv Johann Philipp, nr 2420, s.p.; Des Heiligen Romischen Reichs-Staats Acta..., s. 617.

37 B. von Poten, Tettau Julius Ernst von, Allgemeine Deutsche Biographie 37 (1894), s. 594-596, https://www.deutsche-biographie.de/pnd138607265.html\#adbcontent (dostęp: 02.04.2020); The cultivation of monarchy and the rise of Berlin: Brandenburg-Prussia 1700, ed. K. Friedrich, S. Smart, Farnham 2010, s. 393.

38 État présent des Princes, qui on fait la Requisition, s.l., s.a., Staadarchiv Würzburg (Residenz), Schönborn - Archiv, Korespondenz - archiv Johann Philipp, nr 2420, s.p.; Des Heiligen Romischen Reichs-Staats Acta..., s. 617. 
Bareuth-Ansbach mogło zdaniem anonimowego autora dokumentu wystawić maksymalnie oddział liczący 1500 żołnierzy, ale i tak tamtejszy książę George Frederick II z domu Hohenzollern bezwzględnie współpracował z cesarzem i, co oczywiście zrozumiałe, z elektorem brandenburskim Fryderykiem III ${ }^{39}$.

Kolejnym wymienionym miejscem analizowanym we wspomnianym dokumencie było margrabstwo Baden-Durlach, którego władca - Friedrich VII Magnus, nie był w stanie wystawić więcej niż oddział liczący 2000 ludzi. W 1703 r. książę prawdopodobnie współpracował w trakcie działań wojennych z królem pruskim Fryderykiem I, na którego oddziały czekał, wstrzymując zapewne dalsze działania militarne, o czym skrupulatnie doniósł do Londynu sekretarz angielski w Hadze James d'Ayrolles. W czasie wojny o sukcesję hiszpańską ziemie margrabstwa zostały poważnie zniszczone przez armię francuską, a liczba ludności spadła aż o jedną czwartą ${ }^{40}$.

Księstwo Gotha, czyli Sachsen-Gotha, podobnie jak Baden-Durlach, nie było w stanie, zdaniem autora dokumentu, wystawić więcej jak 2000 żołnierzy, choć w 1697 r. dysponowano jeszcze liczbą 3000 ${ }^{41}$. Niejako przy okazji nawiązano także do kwestii politycznych związanych z deklaracjami nowego księcia Coburga złożonymi już w Wiedniu, a zapewne dotyczącymi możliwej współpracy wymienionego z cesarzem Leopoldem VI ${ }^{42}$.

39 État présent des Princes, qui on fait la Requisition, s.l., s.a., Staadarchiv Würzburg (Residenz), Schönborn - Archiv, Korespondenz - archiv Johann Philipp, nr 2420, s.p.; Des Heiligen Romischen Reichs-Staats Acta..., s. 617.

40 État présent des Princes, qui on fait la Requisition, s.l., s.a., Staadarchiv Würzburg (Residenz), Schönborn - Archiv, Korespondenz - archiv Johann Philipp, nr 2420, s.p.; J. d'Ayrolle do nn, Haga 14 sierpnia 1703, BL, Add MS 28914, k. 256-257; Des Heiligen Romischen Reichs-Staats Acta..., s. 617.

41 État présent des Princes, qui on fait la Requisition, s.l., s.a., Staadarchiv Würzburg (Residenz), Schönborn - Archiv, Korespondenz - archiv Johann Philipp, nr 2420, s.p.; James d'Ayrolles do Conseiller Pensonaire, 24 marca/3 kwietnia 1697, BL, Add MS 28899, k. 137; Des Heiligen Romischen Reichs-Staats Acta..., s. 617.

42 État présent des Princes, qui on fait la Requisition, s.l., s.a., Staadarchiv Würzburg (Residenz), Schönborn - Archiv, Korespondenz - archiv Johann Philipp, nr 2420, s.p.; Des Heiligen Romischen Reichs-Staats Acta..., s. 617. 
Wolfenbüttel zdaniem autora omawianego rękopisu nie był w stanie wystawić więcej niż 3000 żołnierzy, a liczba ta była niewystarczająca nawet do obrony miasta. Ponadto uważano, że to książę Rudolf August, mimo wspólnych rządów z bratem Antonim Ulrykiem, był rzeczywistym dowódcą wojskowym. Oceniano również, że ostatni z wymienionych nie będzie „ne le sera jamais agir contre la Partie”, czyli przeciwko stronnictwu francuskiemu. Dowodem na to miała być jego odmowa połączenia swoich żołnierzy z oddziałami saskimi ${ }^{43}$. Antoni Ulryk rzeczywiście opowiedział się po stronie Ludwika XIV, w przeciwieństwie do swojego brata, którego po najechaniu Wolfenbüttel przez wojska hanowersko-lüneburskie cesarz Leopold VI mianował jedynym regentem księstwa ${ }^{44}$.

Wydaje się, że autor analizowanego dokumentu nie miał jednak dokładnych wiadomości dotyczących możliwości mobilizacyjnych księstwa. Pod koniec listopada 1701 r. Wolfenbüttel dysponowało bowiem 8000 żołnierzy, a tamtejszy władca zamierzał zaciągnąć dodatkowe 4000, chcąc osiągnąć ostateczną liczbę 12000 ludzi ${ }^{45}$.

Zupełnie inaczej w omawianym rękopisie przedstawiała się analiza dotycząca Danii, w której brak jest konkretnych wyliczeń możliwości militarnych tego królestwa. Tekst sprowadza się do stwierdzenia, że możliwości i siły Danii są znane. Zaraz potem autor dokumentu dodał, że nie jest pewne, czy będzie ona chciała zawierać jakieś sojusze, a co za tym idzie angażować się w kwestie wojny. Dlatego uznano, że jest ona politycznie niewiarygodna i w dodatku niestabilna - „que Mr Plessen est rétabli à la tête des affaires" ${ }^{\prime 6}$. Chodziło tutaj najprawdopodobniej o Christiana Siegfrieda von Plessena, który do 1700 r. sprawował funkcję ministra finansów, ale

43 État présent des Princes, qui on fait la Requisition, s.l., s.a., Staadarchiv Würzburg (Residenz), Schönborn - Archiv, Korespondenz - archiv Johann Philipp, nr 2420, s.p.; Des Heiligen Romischen Reichs-Staats Acta..., s. 617-618.

44 http://welfen.de/AntonUlr.htm (dostęp: 18.09.2018); http://www.pierre-marteau.com/resources/anton-ulrich.html (dostęp: 18.09.2018).

45 Weisbrod do W. Ellis, Hanover 25 listopada 1701, BL, Add MS 28910, k. 44-45.

46 État présent des Princes, qui on fait la Requisition, s.l., s.a., Staadarchiv Würzburg (Residenz), Schönborn - Archiv, Korespondenz - archiv Johann Philipp, nr 2420, s.p.; Des Heiligen Romischen Reichs-Staats Acta..., s. 618. 
ostatecznie został zmuszony do odejścia przez konkurencyjne fakcje dworskie związane z Ludwikiem XIV. Następnie był duńskim przedstawicielem w Londynie. Wydaje się, że autor interesującego nas dokumentu błędnie zakładał, że przeciwny Francji von Plessen może powrócić na swoje stanowisko $^{47}$.

W rzeczywistości w 1700 r. prowadzono rozmowy, których celem miało być zawarcie sojuszu między cesarzem Leopoldem VI a królem duńskim Fryderykiem IV Olenburgiem. Dyplomaci wiedeńscy oferowali w zamian za współpracę 150000 talarów rocznych subsydiów. Żądania duńskie opiewały natomiast na kwotę $200000^{48}$. W rzeczywistości duńskim epizodem wojny o sukcesję hiszpańską było uderzenie wojsk tego kraju na posiadłości księcia holsztyńsko-gottorpskiego, którego wsparły państwa morskie - Anglia i Holandia. Szwecja z kolei zaatakowała oddziały duńskie oblegające Tönningen. Ostatecznie jednostki Karola XII zagroziły Kopenhadze, co spowodowało wycofanie się z działań wymienionych państw morskich i w konsekwencji przystąpiono do traktatów, które zakończyły duński udział w zmaganiach europejskich ${ }^{49}$.

Analizowany powyżej dokument kończy się podsumowaniem, w którym jego anonimowy autor zwraca uwagę, że z dużą dozą prawdopodobieństwa można uznać, że poza Danią wszyscy świeccy książęta Rzeszy, ale chyba w tym konkretnym twierdzeniu miał on na myśli wymienionych przez siebie, nie są w stanie wystawić pojedynczo więcej jak 1000 żołnierzy, a każde zwiększenie tej liczby będzie wymagało odpowiednich subsydiów z Francji. Dopiero potem będzie można wykorzystać te oddziały w wojnie

47 État présent des Princes, qui on fait la Requisition, s.l., s.a., Staadarchiv Würzburg (Residenz), Schönborn - Archiv, Korespondenz - archiv Johann Philipp, nr 2420, s.p.; Des Heiligen Romischen Reichs-Staats Acta..., s. 618.; J. H. F. Berlien, Der Elephanten-Orden und seine Ritter. Eine historische Abhandlung über die ersten Spuren dieses Ordens und dessen fernere Entwicklung bis zu sejner gegenwärtigen Gestalt, und nächstdem ein Material zur Personalhistorie, nach den Quellen des Königlichen Geheimen-Staatsarchivs und des Königlichen Ordenscapitels-Archivs zu Kopenhagen, Kopenhagen 1846, s. 80; A. H. Thomas, Historical dictionary of Denmark, Lanham-Boulder-New York-London 2016, s. 413.

48 W. Aldersey do nn, s.l. 28 stycznia 1700, BL, Add MS 28907, k. 137-138.

49 W. Czapliński, K. Górski, Historia Danii, Wrocław-Warszawa-Kraków 1965, s. 221-222. 
o sukcesję hiszpańską. W przeciwnym wypadku siły te zostaną na pewno użyte przez cesarza, który będzie zabiegał, aby tereny te nie znalazły się w orbicie wpływów francuskich. $Z$ drugiej strony dyplomacja Ludwika XIV miała rozpowszechniać informację o rzekomym jarzmie, które miałby narzucić na wymienione księstwa cesarz. Ostatecznie autor doszedł do wniosku, że całe to zamieszanie było w zasadzie wynikiem wrogości wobec Francji Antoniego Urlika z Wolfenbüttel, biskupa Münster i Ludwika Wilhelma von Baden-Baden, a ocena ta była oczywiście jak najbardziej trafna. Dodatkowo wszyscy możliwi sojusznicy Wersalu obawiali się, że ich ewentualne plany aliansu z Ludwikiem XIV mogły przestać być poufne, co na pewno ściągnęłoby na nich zemstę cesarza, czego się powszechnie obawiano.

Politycy i dyplomaci francuscy zdawali sobie doskonale sprawę z nieuchronności konfliktu militarnego o schedę po hiszpańskich Habsburgach. Wiedzieli także, że w tym przypadku ważne będzie poparcie państw Rzeszy Niemieckiej, a teren ten był już tradycyjnie miejscem rywalizacji najpierw Paryża, a potem Wersalu z Wiedniem. Szczególnie obserwowano tzw. linię Renu i okoliczne księstwa niemieckie, choć w analizowanym powyżej dokumencie można znaleźć wyjątki od tej zasady, nawiązującej wszakże do dawnej polityki kardynała Armanda Jeana Richelieu. Ewentualne sojusze mogły w części neutralizować aktywność operacyjną armii cesarskiej lub jej sojuszników. Z danych przedstawionych w omawianym rękopisie można także wnioskować, że Francja nie miała w wymienionych państwach oddanych czy raczej zdecydowanych sojuszników, co może świadczyć w pewien sposób o defensywie dyplomatycznej i politycznej Wersalu. Być może było to spowodowane wcześniejszą działalnością Ludwika XIV, jego agresywnością dyplomatyczną w czasie tzw. réunion. Może tego dowodzić także częste odwoływanie się w analizowanym dokumencie do lat 70. XVII w., kiedy to niektóre z wymienionych w rękopisie państw współpracowały politycznie z Ludwikiem XIV. Tak było choćby w przypadku Würzburga pod rządami biskupa Johanna Philippa von Schönborna, stąd konieczne stało się odwołanie w prezentowanym szkicu do wydarzeń poprzedzających powstanie „Etat présent des Princes, qui on fait la Requisition”. Z rękopisu wyłania się obraz regionów Rzeszy Niemieckiej, choć nie tylko, zdecydowanie 
niesprzyjających Francji, czasem już będących w sojuszu z cesarzem Leopoldem VI. Mimo to stanowi on niezwykle interesujące świadectwo działalności ówczesnej dyplomacji. Miała ona na celu nie tylko przygotowywanie odpowiednich sojuszy politycznych i wojskowych, ale również przez swoje agendy przedstawienie oceny sytuacji, która ostatecznie winna zdecydować o kierunkach podejmowanych działań. 
